\title{
QUALITY ASSESSMENT ON SOME SOAPS SOLD IN NIGERIA
}

\author{
0. Idoko ${ }^{1, *}$, S. A. Emmanuel ${ }^{2}$, A. A. Salau ${ }^{3}$ and P. A. Obigwa ${ }^{4}$ \\ 1,2,3,4, Chemistry Advanced Research Center, Sheda Science \& TeChnology Complex, FCT Abuja, NigERIA \\ E-mail adresses: ${ }^{1}$ samuelidoko2015@yahoo.com, ${ }^{2}$ sawemmy@yahoo.com,3creamysal@yahoo.com, \\ ${ }^{4}$ paddyobigwa@yahoo.com
}

\begin{abstract}
Fifteen soaps were purchased from the main market in Gwagwalada Area Council of FCT, Nigeria. The soaps are Sunlight, MP3, Canoe, 4B, Glide, Lux, Joy, Imperial leather, Premier, Eva Classique, Dettol, Safeguard, Tetmosol, Septol and Premier cool. The qualities of soaps were assessed based on the following parameters; free caustic alkali, volatile matter, matter insoluble in alcohol(MIA), total fatty matter(TFM), pH, cleaning properties, washing properties and foam/lathering properties. The results obtained showed that all the soaps analyzed are good quality soaps safe for the skin.
\end{abstract}

Keywords: soaps, quality assessment, free alkali, $\mathrm{pH}$, total fatty matter.

\section{INTRODUCTIONS}

Soaps are sodium or potassium salts of fatty acids. Soap is the oldest product which dates back to around 2800BC in Ancient Babylon [1]. Soap was prepared by heating animal fat or oil with wood ashes. Wood ashes contain potassium carbonate and sodium carbonate which make the solution basic. The modern commercial method of making soap involves boiling fats or oils in aqueous sodium hydroxide or potassium hydroxide and adding sodium chloride or potassium chloride to precipitate the soaps respectively. The soap is then dried and pressed into bars. Perfumes can be added for scented soaps, dyes can be added for coloured soaps, sand can be added for scouring soaps, and air can be blown into the soaps to make if float [2].
The features and characteristics of soap product that is to satisfy the needs of a consumer is its quality. However, toilet soaps sold directly to consumer are usually made to manufacturers own formulations and specifications, rather than to any official quality specifications, although such specifications might perhaps be involved if questions of trade description arise. Thus the need for constant quality surveillance on the commercially available toilet soaps sold in the open markets is important [3]. Toilet bars are filled soap tablets but often mixed with synthetic detergents to give a rich creamy lather desired of most soap products. This also have the advantage of not leaving scum deposits in the bath or wash basin in hard water and is also cost effective [4].

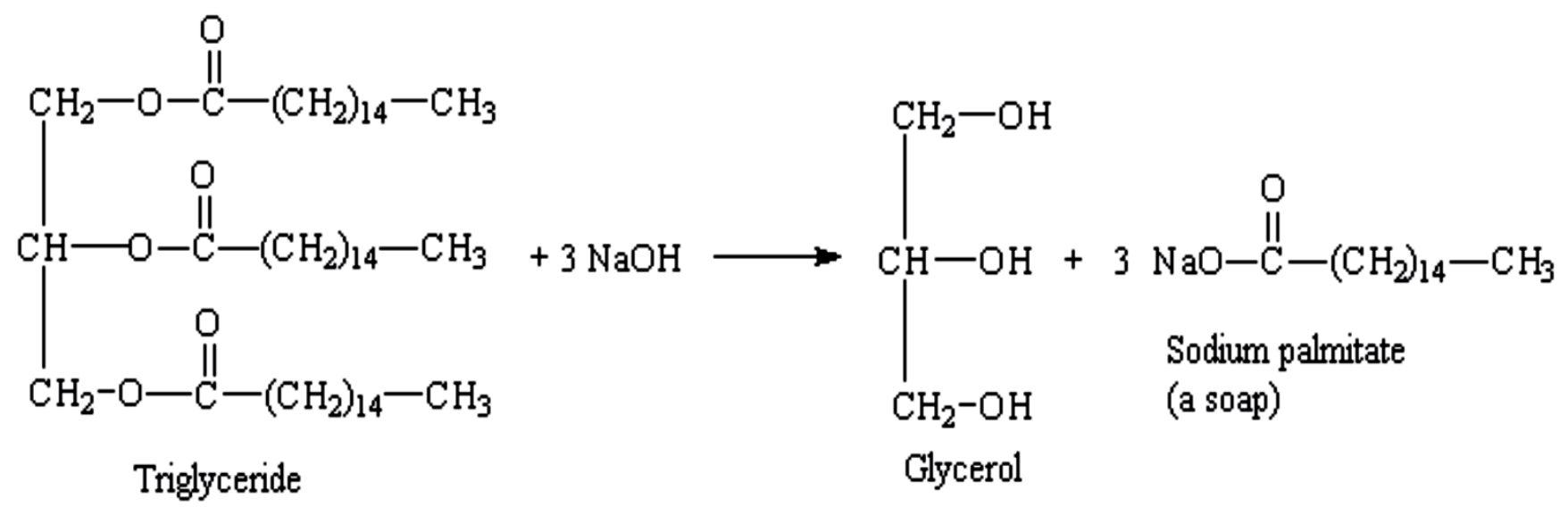

Fig.1: Hydrolysis of a Triglyceride (fat)

* Corresponding author, tel: $+234-706-868-8448$ 
Toilet soap tablets are premium soap products that have strict specifications of fine texture free from objectionable odour and have good lathering and cleansing properties $[1,6]$. The fatty acids, stearic, palmitic, myristic, lauric and oleic acids, contribute to lathering and washing properties of the soaps [9]. The chemical characteristics of soap depend on several factors; the strength and purity of alkali, the kind of oil used, completeness of saponification [7].

Poor quality soaps can cause skin discomforts such as acne, eczema, hives, rashes, skin irritation and possibly lead to cancer [4]. Although soap is effective in removing grime and is relatively inexpensive, alkaline soaps or those with high content of percentage free alkali can cause skin irritation, dryness and scaling which can predispose the skin to fungal attacks $[4,6]$. This is because the excess alkali will saponify the fats and oils, normally found on the skin as a protective coat, to form soluble soap and therefore get washed away, thereby rendering the skin dry. Consequently, good toilet soap should contain little or no free alkali. Super fatted products, which are mild to use on the skin are premium products. Indication of this is also high \%UFM, \%Rosin TFM and \%Glycerol. However, products with very high glycerol will tend to be very soft and the economy of usage is placed at a disadvantage [2]. Some physicochemical properties include moisture content, total fatty acids (TFM), pH, free alkali, matter soluble in alcohol and percent chloride [8].

Soap is an anionic surfactant used in conjunction with water for washing and cleaning. Although the reaction is shown as one step reaction, it is in fact two steps. The net effect as that the ester bonds are broken. The glycerol turns back into an alcohol. The fatty acid portion is turned in to a salt because of the presence of a basic solution of the $\mathrm{NaOH}$. In the carbonyl group, one oxygen now has a negative charge that attracts the positive sodium ion [9]. This work is carried out to assess the quality of some solid soaps sold in Nigerian markets.

\section{MATERIALS}

The fifteen soaps namely; laundry (sunlight, MP3, Canoe, 4B and Glide), toilet (Lux, Joy, Imperial leather, Premier and Eva classique), antiseptic (Dettol, Safeguard, Tetmosol, Septol and Premier cool) were purchased from main market in Gwagwalada Area Council of Abuja, Nigeria. The chemicals used were laboratory absolute ethanol $\left(\mathrm{C}_{2} \mathrm{H}_{5} \mathrm{OH}\right)$, Hydrogen Chloride $(\mathrm{HCl})$, and distilled water.

\section{METHODS}

\subsection{Free Caustic Alkali}

Free caustic alkali was determined by the method described by Onyango et. al.[16] . According to these method 5 grams of finished soap was weighed and dissolved in $30 \mathrm{~mL}$ of ethanol. Few drops of phenolphthalein indicator and $10 \mathrm{~mL}$ of $20 \% \mathrm{BaCl}_{2}$ were added. The resulting solution was then titrated against $0.05 \mathrm{M} \mathrm{H}_{2} \mathrm{SO}_{4}(\mathrm{aq})$. The volume of the acid obtained was calculated using the formula:

$$
F C A=\frac{0.31}{W} \times V_{A}
$$

where; VA is the Volume of acid, $W$ is the Weight of soap and FCA is the Free caustic alkali

\subsection{Matter Insoluble in Alcohol}

Five grams of soap sample was dissolved in $50 \mathrm{ml}$ hot ethanol and quantitatively transferred in a pre-weighed filter paper. The residue was dried in the oven at $105^{\circ} \mathrm{C}$ for 30 minutes, cooled and weighed again then reading taken. The calculation of matter insoluble in alcohol (MIA) was carried out using [9]:

$$
M I A=\frac{W s-F P}{w} \times 100
$$

where: Ws is the Weight of sample + filter paper, FP is the Weight of filter paper and $W$ is the Weight of the sample

\subsection{Determination of $\mathrm{pH}$}

$2 \mathrm{~g}$ of soaps were added into $20 \mathrm{ml}$ distilled water and shaken and the soap suspensions were allowed to stay for at least 12 hours before the $\mathrm{pH}$ meter was inserted into a beaker containing the various soap suspensions, and the readings were recorded [2].

\subsection{Determination of Free Fatty Matter}

The total free fatty matter (FFM) was obtained using:

$$
F F M=\frac{100-(M C-M I A)}{1.085}
$$

where: $M C$ is the Moisture content and MIA is the Matter insoluble in alcohol[2].

\subsection{Moisture/Volatile Matter}

For the determination of moisture content, 5 grams of samples was accurately weighed using analytical balance of sensitivity $0.1 \mathrm{mg}$ into dried tarred moisture dish in an oven for $2 \mathrm{hrs}$ and temperature of $101^{\circ} \mathrm{C}$ and repeated until a constant weight was reached. The $\%$ moisture was calculated using the following formula [10].

$$
\% \text { Moisture }=\frac{C_{S}-C_{L}}{C_{S}-C_{W}} \times 100
$$


where; $C W$ is the Weight of crucible, $C S$ is the Weight of crucible + sample, and $C L$ is the Weight of crucible + sample after floating

\subsection{Washing Properties}

A small amount of the dry soap was used to wash the hand using deionized_water. The lathering properties and the "feel" of the soap was taken (very slippery, greasy, or about normal).

\subsection{Foam Stability}

$1 \%$ of the soap samples were prepared and equal amount of the soap solution was measured into test tubes. The solution was shaken vigorously for $1 \mathrm{~min}$ and allowed to stand for five minutes. The height of the foam was observed and recorded.

\subsection{Cleaning Properties}

A drop of used oil was placed on strips of filter paper. The strips was placed into test tubes containing the $1 \%$ soap solutions. The soap solutions was then shaken vigorously and allowed to stay for 2 mins. The filter paper was removed and rinsed with water. The cleansing power was observed and recorded.

\section{RESULTS AND DISCUSSION}

The physicochemical properties of the soaps are shown in Table 1 . The moisture content result range between 8.36-18.72\%. This indicates that most of the soaps analyzed will not favour the growth of microbes since they are within the recommended value of 10-20\%[1112]. Lux, canoe and septol has moisture content slightly higher than the standard. The Implication of high moisture content in soap is that the excess water could possibly react with any unsaponified neutral fat to give free fatty acid and glycerol in a process called hydrolysis of soap on storage. Moisture content is a parameter that is used in assessing the shelf -life of a product [13].

Free caustic alkali is one of the parameters that determine the abrasiveness of any given soap [18].The free caustic alkali results of MP3, Glide, Dettol, and Safeguard soaps showed no sign of free caustic alkali, whereas the other soaps have values ranging from $0.06-0.22 \%$. These results fall within the standard value of $5 \%$ max declared by Bureau of Indian Standards (BIS) and 2\% max declared by ISO specification [14]. It is an indication that the soaps will not be harsh on the skin and cloth [18].

Matter insoluble in alcohol (MIA) is a parameter that is used to determine the purity of soap [10]. It is the measure of non-soap ingredients known as builders or fillers such as sodium silicate, sodium phosphate, sodium carbonate and minor constituents such as bleachers, whitening agents and fluorescing agents in the finished product. The soap with high MIA values suggests that it contained high level of impurities which may be attributed to the level of impurities of alkali used for producing the soap [10]. The values of MIA of the soaps ranged between $36-77 \%$.

The total fatty matter (TFM) is one of the most important characteristics describing the quality of soap It is defined as total amount of fatty matter, mostly fatty acids, that can be separated from a sample after splitting with mineral acid, usually $\mathrm{HCl}$.

Table 1: Physicochemical Chemical Properties of the soaps

\begin{tabular}{lccccc}
\hline Samples & $\begin{array}{c}\text { Moisture Content } \\
\%\end{array}$ & $\begin{array}{c}\text { Free Alkali } \\
\%\end{array}$ & $\begin{array}{c}\text { Matter insoluble in alcohol } \\
\%\end{array}$ & $\begin{array}{c}\text { Total Fatty matter } \\
\%\end{array}$ & $\mathrm{pH}$ \\
\hline Sunlight & 13.24 & 0.06 & 53 & 41.76 & 9.85 \\
MP3 & 14.05 & NIL & 45 & 40.95 & 10.04 \\
Canoe & 16.04 & 0.22 & 43 & 40.96 & 10.51 \\
4B & 14.94 & 0.04 & 46 & 39.06 & 10.31 \\
Glide & 11.00 & NIL & 54 & 35.00 & 10.09 \\
Lux & 16.65 & NIL & 48 & 35.35 & 10.23 \\
Joy & 11.96 & 0.08 & 58 & 30.04 & 10.10 \\
Imperial & 11.92 & 0.08 & 66 & 22.08 & 10.12 \\
Leather & 15.94 & 0.06 & 64 & 20.26 & 10.40 \\
Premier & 9.74 & 0.06 & 65 & 25.26 & 10.25 \\
Eva Classique & 7.70 & NIL & 77 & 15.30 & 10.17 \\
Dettol & 8.36 & NIL & 73 & 18.64 & 9.64 \\
Safeguard & 10.73 & 0.06 & 64 & 25.27 & 10.12 \\
Tetmosol & 18.72 & 0.12 & 39 & 42.28 & 9.96 \\
Septol & 14.14 & 0.02 & 47 & 38.86 & 9.93 \\
Premier Cool & & & & & \\
\hline
\end{tabular}


The total fatty matter (TFM) values ranged between $15.30-42.28 \%$. The values are lower than that of the International Standard Organisation (ISO). This could be as a result of so many additives like fillers, preservatives, colour etc. in the soaps to confer special properties to the soaps [15]. The lower TFM value is also due to presence of unreacted $\mathrm{NaOH}$ in the mixture [16].

soaps with free alkali and low \% TFM must have been produced with either low-purity fat/ oil or super fatted with super fatting agents like jelly, lanoline, stearin or coconut oil. This will make the products user-friendly as it will be mild on the skin [1].

The $\mathrm{pH}$ result shown in Table 1 . Indicates that the range is between 9.64-10.51. The $\mathrm{pH}$ values for all the soaps fall within the range for $\mathrm{pH}$ for good soaps (7-10) [17].

The other physical analysis carried out on the soaps shows that all the soaps analyzed possess very good cleaning properties, normal washing properties and very stable foam/lathering properties.

\section{CONCLUSION}

On a general note, the fifteen soaps analyzed in this work shows good qualities that makes them safe for use.

\section{REFERENCES}

[1] Woollatt, E. The Manufacturer of Soaps Other Detergents and Glycerin, 1st Edition, Ellis Hardwood Ltd, West Sessux, England 34-35, 4755, 267 and 284, 1985.

[2] Ossai E. K. Preparation and Characterization of Metal Soaps of Cocos Nucifera Seed Oil . Appl. Sci. Environ. Manage, 18(2), 359-363, 2014.

[3] Nangbes J. G., Zukdimma N. A., Wufem, B. M., Lawam T. D. and Dawam N. N. Quality Survey and Safety of Some Toilet Soaps in the Nigerian Market: A Case Study of B/Ladi, Bokkos and Pankshin, Plateau State. IOSR Journal of Applied Chemistry (IOSR-JAC) 7(7), 29-35, www.iosrjournals.org 2007.

[4] Butler H. Pounchers Perfumes, Cosmetics and Soaps vol. 39th edition. Blackier Academics and
Professional, London 393-395, 451-452, 454-457, 464-468 and 481-82, 1987.

[5] Bruice P. Y. Organic Chemistry, Prentice Hall International Inc. Eaglewood Cliff, New Jersey, 736. 1995.

[6] SON. Nigerian Industrial Standard; Guidelines for Classification and Sampling Cosmetics and Toiletries. Standards Organization of Nigeria, Federal Ministry of Industries 9. 1997.

[7] Ossai E. K. Preparation and Characterization of Metal Soaps of Cocos Nucifera Seed Oil. J. Appl. Sci. Environ. Manage, 18(2), 359-363, 2014.

[8] Ahmed I. Palm Oil Research Institute of Malaysia (PORIM), Selangor, Malaysia, 1-17, 1984.

[9] www.trp.org.in

[10] Ogunsuyi H. O. and Akinnawo C.A. Quality Assessment of Soaps Produced from Palm Bunch Ash-Derived Alkali and Coconut Oil. J. Appl. Sci. Environ. Manage. 16 (4), 363-366, 2012.

[11] Joselany A. C., Maria A. L., Maira Di Ciero M., José C. S. Paulo Roberto L. P. Identification of Bacterial Contamination In Liquid Soap For Hospital Use, Rev. esc. enferm. SP., 45(1), 2011.

[12] Encyclopedia of Industrial Chemical analysisInterscience Publishers division of John Wiley\& sons. 18, 179, 180, 2007.

[13] Tewari k. S. A Textbook of Chemistry. $3^{\text {rd }}$ Edition Vikas publishing House PVT Ltd. 26, 594600. 2004.

[14 Bureau of Indian standards, DOC. CHD 20 (2), 2011.

[15] The International standard specification for soaps, ISO 685: 1975.

[16] Onyango P., Vivian O., Nathan A O, Linda M., Wesley N. O. Assessment of the Physicochemical Properties of Selected Commercial Soaps Manufactured and Sold in Kenya. Open Journal of Applied Sciences , 4, 433-440, 2014.

[17] www.soap-made-easy.com

[18] Onyekwere C. Cassava Peels Ash: An Alternative Source of Alkali in Soap Production. BEng Thesis, Department of Chemical Engineering, University of Port-Harcourt, PortHarcourt, 1-33, 1996 